\title{
UKRAINIAN EMIGRATION IN POLAND: FROM "EARNERS" TO HIGHLY QUALIFIED SPECIALISTS
}

\author{
Oleksiy Musiyezdov \\ Doctor of Science (Sociology), Associate Professor, Professor Department of Sociology V. N. Karazin Kharkiv \\ National University, 4, Svobody Sq., Kharkiv, 61022, Ukraine, \\ email: musiyezdov@gmail.com, ORCID ID https://orcid.org/0000-0002-2929-7333
}

The article deals with the Ukrainian emigration to Poland. The article emphasizes that migration is a normal phenomenon in the global world, and therefore it is important not to dramatize the situation but to pay more attention to the adaptation of migrants in the recipient countries. Main terminology used for migrants and migration' description is sharpened. It is emphasized that it is not appropriate to treat any migration from Ukraine as "labor migration". The article provides quantitative data on Ukrainian migration abroad and its dynamics as well as results of researches on migrational intentions and plans. Arguments are being made that the current migration of Ukrainians (after 2010) can be identified as the fifth wave of Ukrainian emigration. The dynamics of the structure of Ukrainian migration abroad is described. Quantitative estimates of Ukrainian migration in Poland are given as well. It is shown that the Ukrainian migration to Poland is changing both quantitatively (growing) and qualitatively: the number of highly educated migrants and those who intend to stay in the country for permanent residence increases. It is reasoned that Poland is interested in Ukrainian workers because they produce reasonable part of Polish GDP and replace Poles who leave the country. That's why Polish state and non-state institutions and organizations try to improve conditions for Ukrainians in Poland and create new opportunities for work and living in the country. It is argued that research on this topic will be an important contribution to understanding the (post)modern society because the role of migrations in it is changing. Migrants' self-awareness and identity are changing as well which leads to changes in ways of adaptation and integration of migrants in recipient countries. In particular, cultural factors that determine the decision about emigration become more important: seeking for the environment that fits best for cultural demands of potential migrants becomes crucial. Differential approaches to different groups of migrants on the basis of sociological researches can be a better ground for practical decisions to improve adaptation of migrants.

Keywords: Migration, emigration, Ukraine, Poland, highly qualified specialists, adaptation.

\section{Українська еміграція у Польщі: від заробітчан до висококваліфікованих спеціалістів}

Олексій Мусієздов доктор соціологічних наук, доцент, професор кафедри соціології Харківського національного університету імені В. Н. Каразіна, майдан Свободи, 4, Харків, 61022, Україна, email: musiyezdov@gmail.com, ORCID ID https://orcid.org/0000-0002-2929-7333

Статтю присвячено українській еміграції у Польщі. У статті наголошується на тому, що міграції є нормальним явищем у глобальному світі, і тому варто не драматизувати ситуацію, а приділити більшу увагу адаптації мігрантів у країнах-реципієнтах. Уточнюється основна термінологія, яка використовується для опису мігрантів та міграції. Зокрема, акцентується наголошується, що не $€$ правильним вважати будь-яку міграцію з України саме «трудовою міграцією». Наводяться кількісні дані щодо української міграції за кордон та її динаміки, 
а також результати досліджень міграційних намірів і планів українців. Наводяться аргументи, що нинішню міграцію українців (після 2010 року) можна ідентифікувати як п'яту хвилю української еміграції. Описується динаміка зміни структури української міграції за кордон. Наводяться кількісні оцінки української міграції до Польщі. Показано, що українська міграція до Польщі змінюється як кількісно (зростає), так і якісно: більшає частина високоосвічених мігрантів та тих, хто має намір залишитися у країні на постійне проживання. Зазначається, що Польща зацікавлена у працівниках з України, оскільки вони заміщують собою поляків, які виїжджають з країни, та створюють помітну частину ВВП Польщі. Тому польські державні й недержавні інституції та організації намагаються покращувати українцям умови перебування у Польщі та створювати нові можливості для життя і роботи в країні. Аргументується, що дослідження з цієї теми стануть важливим внеском до розуміння (пост)сучасного суспільства, оскільки роль міграцій в ньому змінюється. Змінюється самопочуття та ідентичність мігрантів, що змінює й способи адаптації та інтеграції мігрантів в країнах-рецепієнтах. Зокрема більшого значення набувають культурні чинники, які зумовлюють рішення про еміграцію: пошук середовища, яке якнайкраще відповідає культурним вимогам потенційних мігрантів стає принципово важливим. Диференційований підхід до різних груп мігрантів на основі соціологічних досліджень може стати кращою основою практичних рішень для покращення адаптації мігрантів.

Ключові слова: Міграція, еміграція, Україна, Польща, висококваліфіковані спеціалісти, адаптація.

Статья посвящена украинской эмиграции в Польше. В статье отмечается, что миграции являются нормальным явлением в глобальном мире, и поэтому стоит не драматизировать ситуацию, а уделить больше внимания адаптации мигрантов в странах-реципиентах. Уточняется основная терминология, используемая для описания мигрантов и миграции. В частности, акцентируется, что не является правильным считать любую миграцию из Украины именно «трудовой миграцией». Приводятся количественные данные по украинской миграции за границу и ее динамике, а также результаты исследований миграционных намерений и планов украинцев. Приводятся аргументы, что нынешнюю миграцию украинцев (после 2010 года) можно идентифицировать как пятую волну украинской эмиграции. Описывается динамика изменения структуры украинского миграции за границу. Приводятся количественные оценки украинской миграции в Польшу. Показано, что украинская миграция в Польшу меняется как количественно (растет), так и качественно: больше часть высокообразованных мигрантов и тех, кто намерен остаться в стране на постоянное жительство. Отмечается, что Польша заинтересована в работниках из Украины, поскольку они замещают собой поляков, выезжающих из страны, и создают заметную часть ВВП Польши. Поэтому польские государственные и негосударственные учреждения и организации пытаются улучшать условия пребывания украинцев в Польше и создавать новые возможности для жизни и работы в стране. Аргументируется, что исследования по этой теме станут важным вкладом в понимание (пост)современного общества, поскольку роль миграций в нем меняется. Изменяется самоощущение и идентичность мигрантов, меняются и способы адаптации и интеграции мигрантов в странах-реципиентах. В частности, большее значение приобретают культурные факторы, которые обусловливают решение об эмиграции: поиск среды, лучше соответствующей культурным требованиям потенциальных мигрантов становится принципиально важным. Дифференцированный подход к различным группам мигрантов на основе социологических исследований может стать лучшей основой практических решений для улучшения адаптации мигрантов.

Ключевые слова: Миграция, эмиграция, Украина, Польша, высококвалифицированные специалисты, адаптация. 


\section{Introduction}

Migrations are important part of the global world. They can be the result of escaping the dangers of life or seeking for better opportunities for self-development, can cause a lack of human resources and brain drain, or reinforce the economies of countries with the necessary workers. There are probably few countries that are not involved in international migration in one way or another.

According to the Center for Economic Strategy, 6.3 million Ukrainians left and did not return in 2002-2017. Some of them have received the citizenship of other countries, some of them can still return, some live abroad illegally. In 2015-2017, the number of migrant workers from Ukraine was 4 million (about $16 \%$ of the working population). Around 2.62.7 million people can be abroad at the same time. 100 thousand of them left with family, 850 thousand - for the long term [1].

According to the polls conducted by the Rating Group in 2017, 35\% of Ukrainians would like to go abroad for permanent residence (up $5 \%$ from the previous year 2016) [2].

According to the survey of the Kiev International Institute of Sociology commissioned by the newspaper "Dzerkalo Tyzhnia" in 2018, 29\% of respondents were thinking about leaving Ukraine, and about $6.3 \%$ of Ukrainians said that they were not only ready to leave Ukraine, but also do some steps for this [3].

The following KIIS survey that year showed that $7 \%$ were planning to leave Ukraine for long term (longer than 3 months) in the nearest 6 months, with $30 \%$ taking some steps to do it [4].

Is it much or little? Is it good or bad? These questions usually become the key ones in the discourse on migration of Ukrainians. Given the assumption that the "people" must live and work on "their" land, supporting "their" state, and therefore that migrations are rather bad than good, the answers to these questions are pre-programmed: not many people would say that migrations are good, and should be increased. Unless it comes to learning and gaining experience abroad, which will be useful after the return, which is seen as an obvious benefit.

This opinion is also shared by experts [3], it is rooted in the mass consciousness as well.
According to the opinion polls of the Rating

Group, $56 \%$ of respondents consider mass departure abroad to be the biggest threat [5].

Migration researchers Marta Kindler and Olena Fedyuk say: "It hass long been talking about migration in the context of an almost new form of genocide of the Ukrainian people. Migration is seen as a social and national drama" [6].

By agreeing with them, let's try to consider migration more quietly and to go beyond the "state-centric" approach, trying to makes the migrants themselves as a focus of our attention, namely: the possibilities of their adaptation to the recipient country. So, let's clarify that we will be talking mainly about emigration from Ukraine, which is a non-return migration, at least in a short or medium term.

\section{History of Ukrainian migrations}

Researchers identify four or five waves of migration from Ukraine [7, c. 17]; [8, c. 39-41].

The first wave - end of XIX - beginning of $\mathrm{XX}$ century. According to various sources, from 180,000 and 2.5 million people left Ukraine before the First World War. Overcrowding and land scarcity are considered as the main reasons.

The second wave - 1920-1930th. It is considered to be political one because it included a considerable part of Ukrainian politicians and public figures.

The third wave - 1947-1953. Departure or non-return to Ukraine of national movement activists and others who disagreed with the Soviet regime.

The fourth wave - has started from the mid-1980s and continues until now. The main reasons are primarily ethnic and religious first, then - economic ones.

Some researchers distinguish the fifth wave of migration [9]. Thus, at the presentation of the study "Challenges of Contemporary Migration: The Ukrainian Community in Poland" [10], its co-author Aliona Lyasheva argued that now it was precisely different "wave" of migration, not just a "normal" process [11]. To prove this, she cites the following figures about percentage of the Ukrainians living in Poland:

- 10,5\% respondents left for Poland in 1991-2011;

$-12,2 \%$ in $2012-201$;

- $77,3 \%$ after 2015 . 
External migration flows structure, by destination, \% of all migrants (Source: [12, p. 14])

\begin{tabular}{|l|c|c|c|}
\hline State & $2007-2008$ & $2010-2012$ & $2012-2015$ \\
\hline Poland & 6,5 & 14,3 & 38,9 \\
\hline Russia & 47,3 & 43,2 & 26,3 \\
\hline Italy & 14,8 & 13,2 & 11,3 \\
\hline Czech & 11,9 & 12,9 & 9,4 \\
\hline Other countries & 19,5 & 16,4 & 14,1 \\
\hline
\end{tabular}

Also, $54.9 \%$ of respondents indicated that they live in Poland permanently, and $30 \%$ - reside in Poland, i.e. do not leave the country. Such migration should be considered as emigration, not labor migration. And given that, by statistics, Ukraine's migration to Poland is the highest and amounted to almost $39 \%$ in 2012-2015 [12] (Table 1), the observation about the fifth wave seems quite fair. Moreover, it began, as we can see, before Ukraine obtained visa-free status with the European Union (2017) and before the Russian-Ukrainian War (2014) - these events only strengthened the trend and changed the direction of migration.

\section{Basic definitions of migrations}

When researching works on migration, one can find that some sources use the term "migration" [8], while others - "labor migration" [12]; [13], but it becomes clear from the context that these concepts usually are used interchangeably.

The authors of the study, "How Many Ukrainians Departed Abroad, and What the State Has to Do About It" by the Center for Economic Strategies refer to the definition used by the International Organization for Migration: labor migration is "the movement of persons from their home State to another state for the purpose of employment" [14, p. 38]. They use the following definition: "An international labor migrant is a person who wants to be engaged in, engage in, or was engaged in paid activity in a country which she or he is not a citizen of" [1].

Definition of $O$. Rovenchak and V. Volodkoclarifies the situation with terminology, according to them "labor migration" is the migration of persons who, due to the worsening economic situation, move to the other country for a certain period of time solely for the purpose of finding a job and sending money home or making savings to supply their livelihood upon returning home [15, p. 48].
As we can see, the definitions are quite different. The first is very broad, the second defines more clearly the specifics of what is meant by labor migration, namely: the possibility and expectation of returning and supporting the family that remains. At the same time, in both cases, the goal of migration is decisive, which is difficult to find out. Therefore, when dealing with statistics, only indirect methods can determine the part of labor migration ${ }^{1}$. It seems that the reason for this mix of labor migration and migration in general is the explicit or implicit assumption that earnings are the main motive for migration, at least from Ukraine.

We think that's not true, and sociological view should indicate the presence of different factors in taking a decision to move to another country. Of course, living in another country in most cases implies working in that country ${ }^{2}$, so any kind of migration is, in a broad sense, "labor". In any case, labor migration itself is not a matter for our consideration.

Our subject is emigration, or longterm migration, which means (subjectively) "permanent" residence in the recipient country. In fact, it is about self-identity of a person as a resident of the recipient country.

The interpretation of emigration today differs significantly from the vision that was characteristic of the twentieth century and earlier. If emigration meant a break up with a country, family, friends, habitual environment, etc., or at least a very serious

1 For example, by the amount of money that is transferred from the recipient country to the donor country.

2 By the way, it is unclear how to consider the option of outsourcing and outstaffing or international freelancing (widespread among highly educated workers, in particular in the IT industry) - when the employer and in general "work" are in another country - a situation where life and work both are not tied to one country. Obviously, in these cases, some clarifications of terminology should be made. 
complication of contacting with them, now the situation is quite different: people have the opportunity:

- to maintain familiar lifestyle and communication in the new country (A. Appadurai) [16];

- to live in a country, but have a lifestyle that has little to do with it (Z. Bauman) [17];

- to integrate themselves in advance (remotely) to a life in another country in such a way that moving to it is perceived not as a departure from home but as a return.

\section{The meaning of long-term migration for Ukraine}

For Ukraine, as for any donor country, there are both positive and negative effects of long-term migration from the country [1]. The positive ones include potential investments from the diaspora, increased trade with recipient countries. The negative ones are the decline in human capital, the decline in transfers, the worsening of the demographic situation.

"Brain drain" can be mentioned in particular - the departure of highly skilled specialists, who are a necessary resource of any economy. This situation is especially actual one for Ukraine. Thus, according to the International Organization for Migration for 2016, the part of persons with higher education among the Ukrainian migrants is the highest among migrants from the countries of South East Europe. At the same time, the emigration of educated and experienced professionals negatively affects not only the economy of Ukraine, but also migrants themselves if they are engaged in "non-professional" activities in another country. According to the same data, one in three Ukrainian migrants with higher education is doing work that does not require such high qualifications [3].

On the other hand, it would be interesting to find out how many Ukrainians with higher education in Ukraine work in a field related to their education or at least by profession. Therefore, it is unlikely that professional disqualification abroad is so different from that one in Ukraine.

We can add a few positives:

1. Involvement of highly qualified specialists in the global labor market is a benchmark for national youth, who has an example of (professional) self-realization due to their own efforts, and not to for "luck", "relations" and so on. Thus, it contributes to the reduction of the "poverty culture" in Ukraine [18].

2. The same applies to examples of mobility, which contribute to a better understanding of people from other cultures, increasing the competitiveness of professionals, becoming accustomed to not being tied to the place, self-realization in general, etc.

3. The acceptation of values of successful countries by highly qualified specialists keeping connections with Ukraine can lead to spreading these values to Ukraine, which makes the foundation for future development.

4. The example of successful professionals who come from Ukraine may contribute to greater attention from international institutions, whose activities are one of fundamental factors in combating corruption, since domestic institutions and the general culture (in particular, acceptance of everyday corruption [19]) of the population unfortunately provide little reason to be optimistic about this issue.

For example, let's remind $R$. Inglehart's famous idea that economically developed countries share values of selfexpression, while others - values of survival [20]. Accordingly, changes in values are the important factor in the (economic) development of society, and the intensity of internal and external migration contributes to the spread of values of self-expression.

In other words, it is not about transferring money from abroad and not investing in Ukrainian production, but about things thatcaneventuallybecomefundamental to society. It may sound somewhat utopian at the moment, but on the other hand, especially now, in the context of war and geopolitical confrontation we can observe cultural choice, and it is fundamentally important what it will be: whether it is aimed at earnings and survival, or at self-realization.

\section{Ukrainians in Poland}

As we can see, Poland is the main recipient of migrants from Ukraine. According to Bloomberg, about 507,000 people went to Poland from more than 1 million Ukrainians traveling abroad from 2015 to 2017 [21]. In 2018, 36\% of those 
planning to stay abroad for longer than 6 months planned to travel to Poland [4]. 483 thousand Ukrainians are officially employed in Poland [22]. The total number of Ukrainians in Poland in 2017 was estimated from 900,000 [23] to 1.3 million [1], including Ukrainian students (more than 35,000 [24]), and those who live in Poland permanently, i.e. do not require a work permit (about 100,000). According to the National Bank of Poland, about 900,000 Ukrainian migrants were working in Poland in the fall of 2019 [25].

According to the Modular selective survey of the population (households) on labor migration conducted by the state statistics authorities of Ukraine in 2017, in 2015-2017 the total number of migrants to Poland was 506.5 thousand people, including "emigrant workers"3 $16 \%$ (81 thousand) (there are more emigrant workers (44\%) only among those leaving for Italy) [26].

In general, migrants to Poland are younger and less educated than those moving to other countries [1]. It is expected that mainly Ukrainians from the Western Region come to Poland; more often they do jobs that require less skills than they have [26].

According to the study "Challenges of modern migration: Ukrainian community in Poland" [10], 31.9\% of respondents want to stay in Poland for permanent residence, $14.7 \%$ want to move to other countries. Among them, 50.8\% are persons with higher education, $39.9 \%$ are persons aged 31-40 years. Those who have children would like to stay in Poland a little bit more likely than those who don't (34.6\% vs. $29.5 \%)$. That is, emigration is a choice of more educated and experienced people. Experience and frequency of stay in Poland correlate positively with the desire to stay there for permanent residence.

At least two factors can be added to the above-mentioned features of highly educated specialists about their intentions to emigrate: the possibility of professional realization and the closeness of their values to the

3 Emigrant workers are members of a household aged 15-70 years who have been absent from the household for 12 months or more (including persons absent for less than a year who do not plan to return to the household within the next 12 months) for work or seek for employment abroad. This category also includes persons who occasionally visit relatives on weekends, holidays, vacations, etc., while retaining the opportunity to return abroad to continue or seek employment. values of the new society in general and their professional group in particular.

Less than half of respondents get news (44.2\% about events in Poland, 27.4\% about events in Ukraine) from traditional media (television, newspapers, radio), while more than half get it from news sites on the Internet and social networks ${ }^{4}$.

This situation is significantly different from the structure of news consumption in Ukraine, where $85.7 \%$ use television and only $27.1 \%$ use social networks [27, c. 11]. Of course, this is primarily due to the language barrier and the ability to access different sources of information, but the consequences can be significant.

For example, in the election of the President of Ukraine (second round), the results of V. Zelensky / P. Poroshenko among Ukrainian voters in Poland amounted to 51\% / 48\%, respectively, against $73 \%$ / $25 \%$ in Ukraine in general [28]. The issue of elections in both Ukraine and Poland is one of the most discussed in the context of Ukrainian migrants. The number of people who do not participate in elections because of their displacement is important for Ukraine. So the challenge is to give them such an opportunity. For Poland, the topic of Ukrainian migration is primarily about supporting certain political forces that evaluate it in one way or another.

The special issue of migration of Ukrainians to Poland arises in the context of the economies of both countries. According to the National Bank of Poland, in 2015, Ukrainians earned about $\$ 2$ billion and transferred $\$ 1.3$ billion to Ukraine [1]. And these numbers are rising - only in the first half of 2019 Ukrainians transferred $\$ 1.9$ billion from Poland to Ukraine [29]. It means that only Ukrainian migrants from Poland give about 3\% of Ukraine's GDP [30] (and the contribution of all migrants to Ukraine's GDP was about 9\% in 2017 [12]). It should also be noted that the outflow of Ukrainians abroad reduces the unemployment rate in Ukraine.

The contribution of Ukrainian workers to the Polish economy is also great. Ukrainians add $2.5 \%$ of GDP to the Polish economy [31], pay contributions to the social insurance system - in 2017 their number was 316 thousand people, and it increased by $60 \%$ annually [32].

4 Internet 51\% - about events in Poland, 68.5\% about events in Ukraine; social networks 51\% - about events in Poland, 61.1\% - about events in Ukraine. 
Table 2

Differences between Ukrainians who work in Poland and those who wish to live in Poland permanently, \%

\begin{tabular}{|c|c|c|}
\hline & $\begin{array}{c}\text { Total } \\
(\mathrm{N}=855)\end{array}$ & $\begin{array}{c}\text { Those who wish } \\
\text { to live in Poland } \\
\text { permanently }(\mathrm{N}=280)\end{array}$ \\
\hline Would you like to start your own business in Poland? & 27 & 37 \\
\hline Would you like to live in Poland after reaching retirement age? & 27 & 44 \\
\hline Would you like to receive a Polish pension? & 38 & 51 \\
\hline Do you plan to bring your own family to Poland? & 39 & 62 \\
\hline Would you like your children to study in Poland? & 44 & 79 \\
\hline $\begin{array}{l}\text { Would you like your children to stay in Poland for permanent } \\
\text { residence? }\end{array}$ & 44 & 65 \\
\hline
\end{tabular}

Without this contribution, Poland's economic development would be significantly hampered. The reason for the difficulties is the aging of the population in Poland itself and the departure of Poles for work in the western countries. As the German labor market is expected to be more open in 2020 and migrants' wages in the Czech Republic and Slovakia are now 10-15\% higher than in Poland, the outflow of Ukrainian migrants is perceived as a serious problem [33]. Therefore, the Polish employment agencies conduct their own research on these issues.

In particular, in April-May 2019, EWL S.A. together with the Center for Eastern Europe Studies at the University of Warsaw conducted a study "Ukrainians in the Polish labor market: experience, challenges, prospects", which revealed interesting trends [34]:

- among the factors of return to work in Ukraine, higher earnings are consistently the first $(74 \%)$, but others have changed significantly. Thus, importance of such factors of return as economic and political stability ( $51 \%$ vs. $25 \%$ ), corruption ( $41 \%$ vs. $21 \%$ ), increased social protection (32\% vs. $11 \%)$, available health care system ( $27 \%$ vs. $12 \%$ ) and security ( $25 \%$ vs. $12 \%$ ) increased in 2019 comparing with 2018. The part of those who will not return to work in Ukraine under any circumstances has increased from $4 \%$ to $10 \%$;

- the number of migrants with experience of living and working in Poland is increasing;

- Ukrainians in Poland expect higher salaries in 2019 than in 2018;

- the amount of transfers to Ukraine decreases, indicating that the families of former "earners" are also more actively involved in migration;
- the number of migrants who wish to stay in Poland permanently has increased from $22 \%$ in 2018 to $33 \%$ in 2019 .

The researchers paid special attention to those who would like to live in Poland permanently (see Table 2).

Proportion of persons with higher or incomplete higher education among those who wish to live in Poland permanently is $40 \%$ while according to the Center for Economic Strategies among total number of Ukrainians working in Poland their part varies from 17\% to $37 \%$ [1] (in Ukraine in general in 2019 $51,1 \%$ ) [35, c.50-51].

For comparison, according to the survey of the Sociological Group Rating, 24\% of respondents in Ukraine would definitely like to start their own business, $14 \%$ would rather like to do it [36].

So, we can conclude that Ukrainians become more conscious about their role in Poland and disagree more and more with the role of "cheap labor force". Thus, the number of Ukrainians in senior management and leadership positions in Poland increased by $53 \%$ for the year, in particular, in state authorities and local self-government [37].

This is a response to the growing demand in the Polish economy for specialists and toplevel personnel. According to a survey, 17\% of firms are willing to pay Ukrainians more than Polish workers to retain them in Poland [38].

Ukrainians are adapting to Polish society better and better (in particular, they increasingly have Pole friends and more often communicate with Poles) [34]. Many of them would like to live in Poland permanently. Among the last group education level is higher, they have more desire to do business. 
However, a more active group is also more mobile [39], which is of concern to Polish employers.

So, Andrzej Korkus, a spokesman for the EWL S.A. Employment Agency, said: «The Polish monopoly <on Ukrainian workers - $O M>$ is coming to an end. On the one hand, Europe's largest economy, Germany, is opening up for our eastern neighbor. On the other hand, the Ukrainian economy has been growing stronger in recent years. If we are to keep the current GDP growth, which is also positively influenced by our eastern neighbors, we must fight for workers from Ukraine" $[34$, p. 3].

Experts are discussing that about one of four Ukrainians may leave Poland in the nearest future due to visa liberalization, and up to a total of 1.5 million Ukrainians may leave by 2025 [ 40 ].

Therefore, the Polish institutions have to take care of simplifying migration and improving the conditions for Ukrainians in Poland, and that is why Poland is trying to facilitate the invitation and adaptation of migrants from Ukraine at various levels. For example, in Poland, the employment of Ukrainian doctors in Poland is simplified [41]. The conditions for opening a business in Poland and transferring business from Ukraine are simplified, which greatly helps Ukrainians who withdraw from the country as a result of the deterioration of such conditions in Ukraine due to the arrival of new authorities and the implementation of adverse changes in legislation. Ukrainians are also offered various bonuses - health insurance, longer holidays, better social security, etc. [42] - especially for those who speak Polish (language learning is also facilitated [43]). Special state centers are being opened and efforts are being made to promote the adaptation of Ukrainians in Poland [44]; [45].

These efforts are effective and, according to experts, the number of Ukrainians who move from Poland to other countries is not critical - the majority will remain in the country [46]; [47]. So we have one more argument for interpreting the situation in terms of emigration.

At the same time, as we can see, there is a tendency according to which some Ukrainians in Poland gradually move from the category of "earners" to highly educated emigrants.
Although such Ukrainians primarily choose the US, Israel, Germany and Finland, Poland's part of them may increase, especially from those who already have experience in the country. It can be said that Ukrainian migrants are increasingly reproducing the "German model" of adaptation, which is characterized by integration into a new society [48]. Polish researchers also pay attention to this [23]; [49].

If the main motive for low-skilled migrants is the opportunity to earn money, for the highly-skilled ones the main motives are security, quality of institutions (education, medicine), prospects for development. Highly qualified professionals who had a family either left with it immediately (57\%) or transported them after they moved $(30 \%)$ [1]. And as we have seen, this is quite true for Ukrainian immigrants in Poland.

\section{Conclusions and prospects of further researches}

The described situation opens up opportunities for sociological studies of Ukrainian emigration in general, and in Poland in particular. As we can see, there already are examples of such studies. However, it would be fruitful to expand their subject and make them more fundamental. At least, it can be offered to pay special attention to the adaptation of immigrants to their country of residence. Not only obvious linguistic or legal issues can be involved here, but culture in the broad sense, which would be a return to classical sociological topics in this field.

As the "Polish peasant in Europe and America" by W. Thomas and F. Znaniecki [50] became a work on the basis of which the concept of marginality was conceptualized and put into scientific circulation, new researches can significantly contribute to the understanding of the present (post)modern society in general.

As we have mentioned before, (post) modern society is characterized, among other things, by the possibility of living (territorially) in one society, but in fact (by values, norms, way of life, information exchange, communication, etc.) belonging to another one. Z. Bauman, who drew attention to this about 30 years ago, said that this situation questions the sociological understanding of society as such: can we still separate societies by territorial factor or not? [17] 
A. Appadurai in his works draws attention to "imaginary migration" and the ability to preserve the identity of one society or nation, actually permanently residing in another one [16]. (Post)modern society provides new resources and new frameworks for the "imaginative" construction of the human "I" and social worlds - this is also emphasized by K. Kastoriadis, M. Maffesofoli, J. Urry and others [51]; [52]; [53].

It is also worth mentioning that the experience of Ukrainian migration to Poland is encouraging some colleagues to find more optimal concepts to describe the current situation with migration in the global world in general. For example, Alexandra GrzymalaKazlowska and Anita Brzozowska offer the use of the concept of "anchoring", which, in contrast to the common "assimilation", "integration", "adaptation", means finding points of stability and certain rooting in a new society without fostering one's identity (as diasporas do, for example), on the one hand, and without losing it, on the other [54].

Other authors tend to interpret Ukrainian-Polish mobility as local (at least for Western Ukraine) [49]or to speak of a common "transnational social stratification space" (TSSS), inside which territorial migration is social mobility as well [55]. These and other results of theoretical understanding of Ukrainian migration to Poland, as we see, open up considerable prospects for both theoretical and empirical research. In any case, such theoretical work deserves far more attention than it currently has.

The rethinking of society in general and emigration in particular is related to the emphasis on culture. For example, 0. Rovenchak and V. Volodko emphasize the growing role of cultural factor in migration processes and in the decision to move, in particular [15]. One of the factors of decision making is the interpretation of one's identity and its correspondence to a particular society, social or ethnic group, etc. So far, there is very little research on this topic [56]. At the same time, they have obvious practical implications.

It is important to distinguish the different groups of emigrants. For example, some of them may remain those who implement survival strategies, while the rest may be highly educated professionals seeking for self-fulfillment, someone emigrates for economic, political or cultural reasons; someone has better conditions for emigration, someone worse, and so on. Therefore, the culture (values, interests, lifestyle, etc.) of these different groups will obviously have different features and accents. For example, my previous study, which was based on the distinction between "cosmopolitan elites" and "local masses" (M. Castells), found that there were substantially different ways of connection with a place of residence in different groups [57].

In particular, whenitcomes to theoverall facilitation of migration opportunities, which are particularly characteristic of groups with sufficient educational, professional, cultural resources, such groups are increasingly paying attention to the choice of the best place to live and work - a place that will suit not only their practical needs (better earnings, security, infrastructure, services, etc.), but also cultural values (socalled "cultural emigration"). That is, it is a situation well known for urban researchers: "People who possess economic resources usually care about the embodiment of their cultural capital in urban spaces as markers of their personal identity" (S. Zukin) [58]. It is now increasingly repeated at the level of international migration.

Taking into account these differences and peculiarities could help Polish cities and territories invite more effectively and retain those Ukrainian migrants who they need.

Given the new socio-political situation in Ukraine, which is characterized by a gradual change in the geopolitical vector and deteriorating conditions for entrepreneurship, it can be predicted that Ukrainian migration to Poland will increase. More educated Ukrainians will be involved in it more often. And if Poland is able to offer better conditions than its competitors in the labor market (above all, the Czech Republic, Germany, as well as the USA, Israel), the tendency of growth of emigration and permanent residence will remain. Therefore, this makes the research of Ukrainian emigration in Poland extremely significant. 


\section{Bibliography}

1. Скільки українців поїхало за кордон і що державі з цим робити: аналітична записка / Центр економічних стратегій. 11.04.2018. URL: https://ces.org.ua/migration/

2. Динаміка міграційних настроїв українців / Соціологічна група «Рейтинг». 3.10.2017. URL: http://ratinggroup.ua/research/ ukraine/dinamika_migracionnyh_nastroeniy_ukraincev.html

3. Мостова Ю., Рахманін С. Кровотеча. Чому українці покидають свою країну. Дзеркало тижня. 27.01.2018. URL: https:// dt.ua/internal/krovotecha-chomu-ukrayinci-pokidayut-svoyukrayinu-267394_html

4. Міграційні настрої населення України у квітні 2018 року: Прес-реліз / Київський міжнародний інститут соціології. 18.05.2018. URL: https://www.kiis.com.ua/?lang=ukr\&cat=reports \&id $=765$ \&page $=1$

5. Оцінка ситуації в країні (19-22 жовтня 2019 року) / Соціологічна група «Рейтинг». 24.10.2019. URL: http:// ratinggroup.ua/research/ukraine/ocenka_situacii_v_strane_19-22_ oktyabrya_2019_goda.html

6. Кіндлер М., Ляшева А., Федюк О. Дослідниці міграції: «Люди вірили в майбутнє України, у зміни, зараз зовсім не чути такого оптимізму» / Спільне: журнал соціальної критики. 19.04.2017. URL: https://commons.com.ua/uk/issledovatelnicymigracii/

7. Міграція в Україні: факти і цифри / Міжнародна організація з міграції (МОМ). Українське представництво, 2016. 32 с.

8. Ілик Х. В., Коваліско Н. В., Сучасні міграційні процеси і соціальне сирітство: соціологічний дискурс. Львів: ТзОВ «ЛігаПрес», 2019. 234 с.

9. Гелюх М. Усі на вихід: плюси та мінуси трудової міграції 3 України // UA.NEWS. 22.01.2019. URL: https://ua.news/ua/usi-navyhid-plyusy-i-minusy-trudovoyi-migratsiyi-z-ukrayiny/

10. Виклики сучасної міграції: українська спільнота у Польщі : аналітичний звіт / за заг. ред. О. Міхеєвої, В. Сусака. Львів: Український католицький університет, КолірПро, 2019. 188 с.

11. Як жінки уможливлюють трудову міграцію до Польщі. Youtube. Політична критика. 5.11.2019. Виступ Альони Ляшевої на дискусії «П'ята хвиля. Трудова міграція в історіях і цифpax». URL: https://www.youtube.com/watch?v=IveE6TmLfl0\&fea ture=youtu. be\&fbclid=IwAR02YXRhE5YLNzagpObuwiRGXaf8zS1 Bj_zOc3bYs2kboKxnJvewHegpN3Q

12. Лібанова Е. М. Зовнішні трудові міграції українців: масштаби, причини, наслідки. Демографія та соціальна економіка. 2018. № 2. С. 11-26.

13. Кукурудза І. І. Ромащенко Т. І. Україна у світових процесах трудової міграції. Черкаси : ЧНУ імені Богдана Хмельницького, 2012. 252 с.

14. Glossary in migration. International Organization for Migration, 2004. 81 p. URL: https://austria.iom.int/sites/default/ files/IML_1_EN.pdf

15. Володько В.В., Ровенчак О. А. Міжнародна міграція: теорія та практика. Львів: ЛНУ ім. І. Франка, 2015. 412 с.

16. Appadurai A. Modernity at Large: Cultural Dimensions of Globalization. Minneapolis; London: Univ. of Minnesota Press, 1996.

17. Bauman Z. Intimations of Postmodernity. London and New York: Routledge, 1992

18. Культура (субкультури) бідності в Україні. Центр близькосхідних досліджень (AMES), Аналітичний центр УКУ, за підтримки МФ «Відродження», 2019. 56 с.

19. Чабарай Г. Як українці сприймають корупцію. Тиждень. ua. 12.12.2018. URL: https://tyzhden.ua/Politics/224136
20. Вельцель К., Инглхарт Р. Модернизация, культурные изменения и демократия. Последовательность человеческого развития. М.: Новое издательство, 2011. 464 с.

21. Майже 4 мільйони українців $€$ трудовими мігрантами - дослідження // УНІАН. 23.04.2018. URL: https://www.unian. ua/society/10091891-mayzhe-4-milyoni-ukrajinciv-ye-trudovimimigrantami-doslidzhennya.html

22. Михайлишина Д. Украинцы эмигрируют: как это влияет на экономику страны // Ліга.Бізнес. 28.09.2019. URL: https:// biz.liga.net/ekonomika/all/opinion/ukraintsy-emigriruyut-kak-etovliyaet-na-ekonomiku-strany

23. Jaroszewicz M. Migration from Ukraine to Poland. The trend stabilizes : OSW Report (October 2018). Warsaw : Ośrodek Studiów Wschodnich im. Marka Karpia (Centre for Eastern Studies), 2018. 18 p.

24. Чому українські студенти обирають навчання в Польщі // HB (Новое время). 1.10.2018. URL: https://nv.ua/ukr/ ukraine/events/chomu-ukrajinski-studenti-obirajut-navchannja-vpolshchi-2497459.html

25. В Польше подсчитали количество работающих украинских мигрантов // Ліга.Новости. 13.11.2019. URL: https:// news.liga.net/economics/news/v-polshe-podschitali-kolichestvorabotayuschih-ukrainskih-migrantov

26. Зовнішня трудова міграція населення (за результатами модульного вибіркового обстеження): Статистичний бюлетень / Державна служба статистики України. Київ: Держстат, 2017. 36 с. URL: http://www.ukrstat.gov.ua/druk/publicat/kat_u/publ11_u.htm

27. Протидія російській пропаганді та медіаграмотність: результати всеукраїнського опитування громадської думки. Аналітичний звіт. К.: Детектор медіа, 2018. 64 с. URL: https:// detector.media/doc/images/news/archive/2016/136017/DM_ KMIS_ukr_WEB-2.pdf

28. Вибори Президента України 2019. Результати голосування на закордонних виборчих дільницях. Закордонний виборчий округ / Центральна виборча комісія. URL: https://www.cvk. gov.ua/pls/vp2019/wp336pt001f01=720pt005f01=226.html

29. У НБУ розповіли, скільки грошей переказали заробітчани з початку року / Економічна правда. 25.09.2019. URL: https:// www.epravda.com.ua/news/2019/09/25/651982/

30. Валовий внутрішній продукт (ВВП) в Україні 2019 року // Мінфін. 30.09.2019. URL https://index.minfin.com.ua/ua/ economy/gdp/

31. Економічний бум: в Польщі оцінили роль українських заробітчан в зростанні ВВП країни року // OBOZREVATEL. 31.10.2019. URL: https://www.obozrevatel.com/ukr/economics/ ekonomichnij-bum-v-polschi-otsinili-rol-ukrainskih-zarobitchan-vzrostanni-vvp-kraini.htm

32. Українці рятують не лише польський ринок праці, а й принагідно фонд соціального страхування // Наша Польща. Портал товариства українців у Польщі. 4.03.2018. URL: https:// nashapolsha.pl/ukrayintsi-ryatuyut-ne-lyshe-polskyj-rynok-pratsij-prynagidno-fond-sotsialnogo-strahuvannya/

33. Coraz więcej Ukraińców chce wyjechać z Polski // TVN24bis. pl. 14.10.2019. URL: https://tvn24bis.pl/z-kraju,74/puls-biznesucoraz-wiecej-ukraincow-chce-wyjechac-z-polski,977256.html

34. Ukraińcy na polskim rynku pracy: doświadczenia, wyzwania i perspektywy: Raport EWL. Warszawa : EWL S.A.; Fundację Na Rzecz Wspierania Migrantów Na Rynku Pracy «EWL»; Studium Europy Wschodniej Uniwersytetu Warszawskiego, 2019. 24 p.

35. Соціально-демографічні характеристики домогосподарств України у 2019 році (за даними вибіркового обстеження умов життя домогосподарств України. Статистичний збірник. К.: Державна служба статистики України, 2019. 188 с. 
36. Податки та підприємництво: оцінки та очікування / Соціологічна група «Рейтинг». 12.11.2019. URL: http://ratinggroup.ua/ research/ukraine/nalogi_i_predprinimatelstvo_ocenki_i_ozhidaniya.html

37. Збільшилася кількість українців, які працюють на топпосадах у Польщі / Я в Польщі. 23.10.2019. URL: https://www. yavp.pl/uk/novini/zbilshylasia-kilkist-ukraintsiv-iaki-pratsiuiut-natopposadakh-u-polshchi-16656.html

38. Скільки заробляють українці в Польщі. Найсвіжіше дослідження // Наша Польща. Портал товариства українців у Польщі. 7.11.2019. URL: https://nashapolsha.pl/skilky-zaroblyayutukrayintsi-v-polshhi-najsvizhishe-doslidzhennya/

39. Де хочуть жити українці? / Соціологічна група «Рейтинг». 15.03.2018. URL: http://ratinggroup.ua/research/ukraine/ gde_hotyat_zhit_ukraincy.html

40. Będzie dziura na rynku pracy? Do 2025 r. Polskę może opuścić nawet 1,5 mln pracowników z Ukrainy / Gazeta.pl. 14.10.2019. URL: http://next.gazeta.pl/next/7,151003,25307509,w-2020-r-polskemoze-opuscic-nawet-pol-miliona-pracownikow.html

41. У Польщі спроститься працевлаштування лікарів з України / OBOZREVATEL. 24.10.2019. URL: https://www.polskieradio. pl/398/7862/Artykul/2390629,У-Польщі-спроститьсяпрацевлаштування-лікарів-з-України

42. Не зарплатою єдиною. Чим можуть втримати українців польські працедавці // Наша Польща. Портал товариства українців у Польщі. 3.11.2019. URL: https://nashapolsha.pl/nezarplatoyu-yedynoyu-chym-mozhut-vtrymaty-ukrayintsiv-polskipratsedavtsi/

43. Польська мова на старт. Навчальні матеріали можна завантажити з сайту Управління у справах іноземців / Я в Польщі. 23.10.2019. URL: https://www.yavp.pl/uk/novini/polskamova-na-start-navchalni-materialy-mozhna-zavantazhyty-z-saituupravlinnia-u-spravakh-inozemtsiv-16680.html

44. у Польщі створили інфолінію для громадян України // Наша Польща. Портал товариства українців у Польщі. 6.03.2018. URL: $\quad$ https://nashapolsha.pl/u-polshhi-stvoryly-infoliniyu-dlyagromadyan-ukrayiny/

45. Муренець С. Вроцлав - місто можливостей. Як мігрантів з України вчать спілкуванню, лідерству та бути успішними // Я в Польщі. 7.11.2019. URL: https://www.yavp.pl/uk/ukrajintsiv-polshchi/vrotslav-misto-mozhlyvostei-yak-mihrantiv-z-ukrainyvchat-spilkuvanniu-liderstvu-ta-buty-uspishnymy-16752.html

46. Українські заробітчани все більше укорінюються в Польщі // Наша Польща. Портал товариства українців у Польщі. 19.08.2019. URL: https://nashapolsha.pl/ukrayinski-zarobitchanyvse-bilshe-ukorinyuyutsya-v-polshhi/
47. Чи українці поїдуть з Польщі на роботу до Німеччини? Коментар консула України в Гданську // Я в Польщі. 5.11.2019. URL: $\quad$ https://www.yavp.pl/uk/novini/chy-ukraintsi-poidut-zpolshchi-na-robotu-do-nimechchyny-komentar-konsula-ukrainyv-hdansku-16746.html

48. Ровенчак О. А. Соціокультурні характеристики сучасної української еміграції до Німеччини // Вісник ОНУ ім. І. І. Мечнікова. Соціологія і політичні науки. 2016. Т. 21. Вип. 1(24). С. 71-90.

49. Ukrainian Migration to Poland: A "Local" Mobility? // Ukrainian Migration to the European Union. Lessons from migration studies / O. Fedyuk, M. Kindler (eds.); IMISCOE Research Series. Springer Open, 2016. P. 115-131.

50. Thomas W., Znaniecki F. The Polish Peasant in Europe and America // Core Historical Literature of Agriculture (CHLA). Ithaca, NY: Albert R. Mann Library, Cornell University. URL: http://chla. library.cornell.edu/c/chla/browse/title/3074959.html

51. Касториадис К. Воображаемое установление общества; пер. с франц. Г. Волковой, С. Офертаса. М.: Гнозис, Логос, 2003. $480 \mathrm{c}$

52. Maffesoli M. The Time of the Tribes. The Decline of Individualism in the Mass Society. London : SAGE Publications ; Thousand Oaks, New Delhi, 1996.

53. Urry J. Sociology beyond Societies. Mobilities for the twenty-first century. London and New York : Routledge, 2000.

54. Brzozowska A. Grzymała-Kazłowska A. From Drifting to Anchoring Capturing the Experience of Ukrainian Migrants in Poland // Central and Eastern European Migration Review. 2017. Vol. 6. No . 2. Pp. 103-122.

55. Шестаковський О. Поточні тенденції української транснаціональної трудової міграції як соціальної мобільності // Процеси соціальної мобільності в сучасному українському суспільстві: монографія / ред. О. Балакірєвої. Київ: ДУ «Інститут економіки та прогнозування НАН України», 2014. С. 171-202.

56. Ровенчак О., Химович О. Ідентичність потенційного мігранта та міграційна ідентичність: формування і відповідні практики // Соціологія: теорія, методи, маркетинг. 2018. №2. C. 97-116.

57. Мусієздов О, Міська ідентичність у (пост)сучасному українському місті (приклад Харкова та Львова) // Соціологія: Теорія. Методи. Маркетинг. 2016. №3. С. 94-110.

58. The Naked City - Speaker: Professor Sharon Zukin // Youtube. London School of Economics and Political Science (LSE). 5.05.2011. URL: https://www.youtube.com/ watch?v=0J6aymGN2Vo

\section{References}

1. 'How many Ukrainians went out of a border and what state has to do with that': Analytical note (2018) Center for economic strategies 11.04.2018 [online]. Available at: https://ces.org.ua/migration/

2. 'Dynamics of migration intentions of Ukrainians' (2017) Sociological group "Rating" 3.10.2017 [online]. Available at: http:// ratinggroup.ua/research/ukraine/dinamika_migracionnyh_nastroeniy_ukraincev.html

3. Mostova, J., Rakhmanin, S. (2018) 'Blood flow. Why Ukrainians left their country' (2018) Dzerkalo tyzhnya 27.01.2018 [online]. Available at: https://dt.ua/internal/krovotecha-chomu-ukrayincipokidayut-svoyu-krayinu-267394_html

4. Migrantional intentions of population of Ukraine in April 2018: Press-release (2018) Kyiv international institute of sociology 18.05.2018 [online]. Available at: https://www.kiis.com.ua/?lang=u kr\&cat=reports\&id=765\&page $=1$
5. 'Evaluation of the situation in the country (19-22 October 2019)' (2019) Sociological group "Rating". 24.10.2019 [online]. Available at: http://ratinggroup.ua/research/ukraine/ocenka_ situacii_v_strane_19-22_oktyabrya_2019_goda.html

6. Kindler, M., Lyasheva, A., Fediuk, O. (2017) Researchers of migrations: 'People believed in the future of Ukraine, in changes, no one can hear such an optimism now'. Commons: journal of social critique 19.04.2017 [online]. Available at: https://commons.com.

7. Migration in Ukraine: facts and figures (2016) International organization of migration (IOM). Ukrainian office.

8. Ilyk, H.V., Kovalisko N.V. (2019) Contemporary migration processes and social orphanage; sociological discourse. Lviv: TzOV "Liga-Press".

9. Heliukh, M. (2019) Everybody go out: Pluses and minuses ua/uk/issledovatelnicy-migracii/ 
of labor migration from Ukraine. UA.NEWS. 22.01.2019 [online]. Available at: https://ua.news/ua/usi-na-vyhid-plyusy-i-minusy-trudovoyi-migratsiyi-z-ukrayiny/

10. Challenges of Contemporary Migration: The Ukrainian Community in Poland: Analytical report (2019) In O. Mikheieva, V. Susak. (eds). Lviv: Ukrainian catholic university, KolirPro.

11. 'How women enable labor migration to Poland (2019)' Youtube. Political critique. 5.11.2019. Speech by Alyona Lyasheva on the discussion "Five wave. Labor migration in history and figures" [online]. Available at: https://www.youtube.com/watch?v=IveE6Tm Lfl0\&feature=youtu.be\&fbclid=IwAR02YXRhE5YLNzagpObuwiRGXaf 8zS1Bj_z0c3bYs2kboKxnJvewHegpN3Q

12. Libanova, E. M. (2018) 'External labor migrations of Ukrainians: scales, reasons, consequences'. Demography and social economy. № 2. Pp. 11-26.

13. Kukurudza, I. I., Romaschenko T. I. (2012) Ukraine in world processes of labor migration. Cherkasy: Bohdan Khmelnytsky ChNU.

14. Glossary in migration (2004) International Organization for Migration [online]. Available at: https://austria.iom.int/sites/default/ files/IML_1_EN.pdf

15. Volodko, V. V., Rovenchak, O. A. (2015) International migration: theory and practice. Lviv: I. Franko LNU.

16. Appadurai, A. (1996) Modernity at Large: Cultural Dimensions of Globalization. Minneapolis; London: Univ. of Minnesota Press.

17. Bauman, Z. (1992) Intimations of Postmodernity. London and New York: Routledge.

18. Culture (subcultures) of poverty in Ukraine (2019). AMES, Analytical center of UCU, with support by IF "Renaissance".

19. Chabarai H. 'How Ukrainians perceive the corruption' (2018) Tyzgden.ua. 12.12.2018 [online]. Available at: https://tyzhden.ua/Politics/224136

20. Inglehart, R. and Welzel, C. (2005) Modernization, Cultural Change and Democracy: The Human Development Sequence, New York: Cambridge University Press.

21. 'Almost 4 million Ukrainians are labor migrants - research' (2018) UNIAN. 23.04.2018 [online]. Available at: https://www.unian. ua/society/10091891-mayzhe-4-milyoni-ukrajinciv-ye-trudovimimigrantami-doslidzhennya.html

22. Mykhailyshyna, D. (2019) 'Ukrainians emigrate: how it impacts on the economy of country'. Liga.Biznes. 28.09.2019 [online]. Available at: https://biz.liga.net/ekonomika/all/opinion/ukraintsyemigriruyut-kak-eto-vliyaet-na-ekonomiku-strany

23. Jaroszewicz, M. (2018) 'Migration from Ukraine to Poland'. The trend stabilizes: OSW Report (October 2018). Warsaw: Ośrodek Studiów Wschodnich im. Marka Karpia (Centre for Eastern Studies), $18 \mathrm{p}$.

24. 'Why Ukrainian students chose studying in Poland' (2018) NV (Novoie vriemia). 1.10.2018 [online]. Available at: https://nv.ua/ ukr/ukraine/events/chomu-ukrajinski-studenti-obirajut-navchannja-v-polshchi-2497459.html

25. 'Amount of working Ukrainian migrants is counted in Poland' (2019) Liga.News. 13.11.2019. URL: https://news.liga.net/ economics/news/v-polshe-podschitali-kolichestvo-rabotayuschihukrainskih-migrantov

26. External labor migration of the population (on the results of module sample research): Statistical bulletin (2017). Kyiv: Derzhstat [online]. Available at: http://www.ukrstat.gov.ua/druk/publicat/ kat_u/publ11_u.htm

27. Resistance of Russian propaganda and medialiteracy: results of Ukrainian survey. Analytical report (2018). Detector media [online]. Available at: https://detector.media/doc/images/news/ archive/2016/136017/DM_KMIS_ukr_WEB-2.pdf

28. 'Election of the President of Ukraine 2019. Results of voting on foreign electoral district' (2019) Central electoral committee [online]. Available at: https://www.cvk.gov.ua/pls/vp2019/ wp336pt001f01 $=720$ pt005f01 $=226 . \mathrm{html}$

29. We were told by NBU about how many money have been transferred by labor migrants since the beginning of the year // Ekonomichna pravda. 25.09.2019. URL: https://www.epravda.com.ua/ news/2019/09/25/651982/

30. 'Gross domestic product (GDP) in Ukraine in 2019'. Minfin. 30.09.2019 [online]. Available at: https://index.minfin.com.ua/ua/ economy/gdp/

31. 'Economic boom: The role of Ukrainian labor migrants in GDP increase is evaluated in Poland' (2019) OBOZREVATEL. 31.10.2019 [online]. Available at: https://www.obozrevatel.com/ ukr/economics/ekonomichnij-bum-v-polschi-otsinili-rol-ukrainskih-zarobitchan-v-zrostanni-vvp-kraini.htm

32. 'Ukrainians save not only Polish labor market, but social insurance foundation as well' (2018) Nasha Polscha. Portal of the association of Ukrainians in Poland. 4.03.2018 [online]. Available at: https://nashapolsha.pl/ukrayintsi-ryatuyut-ne-lyshe-polskyj-rynokpratsi-j-prynagidno-fond-sotsialnogo-strahuvannya/

33. The more and more Ukrainians want to leave Poland (2019) In: TVN24bis.pl. 14.10.2019 [online]. Available at: https:// tvn24bis.pl/z-kraju,74/puls-biznesu-coraz-wiecej-ukraincow-chcewyjechac-z-polski,977256.html

34. Ukrainians at the Polish labor market: experiences, challenges and perspectives: Report EWL (2019). Warsaw: EWL S.A.; The Foundation for Supporting Migrants on the Labor Market "EWL”; Study of Eastern Europe at the University of Warsaw. 24 p.

35. 'Socio-demographic characteristic of households in Ukraine in 2019 (on the data of sample survey of living conditions of households in Ukraine)'. Statistical collection (2019). Kyiv: Derzhstat. 188 p.

36. 'Taxes and entrepreneurship: evaluations and expectations' (2019) Sociological group "Rating" 12.11.2019 [online]. Available at: http://ratinggroup.ua/research/ukraine/nalogi_i_predprinimatelstvo_ocenki_i_ozhidaniya.html

37. 'Amount of Ukrainians who work on top-positions in Poland increased' (2019) Me in Poland. 23.10.2019 [online]. Available at:https://www.yavp.pl/uk/novini/zbilshylasia-kilkist-ukraintsiv-iakipratsiuiut-na-topposadakh-u-polshchi-16656.html

38. 'How much Ukrainians earn in Poland. The latest research' (2019) Nasha Polscha. Portal of the association of Ukrainians in Poland. 7.11.2019 [online]. Available at: https://nashapolsha.pl/ skilky-zaroblyayut-ukrayintsi-v-polshhi-najsvizhishe-doslidzhennya/

39. 'Where Ukrainians want to live?' (2018) Sociological group "Rating". 15.03.2018 [online]. Available at: http://ratinggroup.ua/ research/ukraine/gde_hotyat_zhit_ukraincy.html

40. 'Will there be a hole in the labor market? By 2025, up to 1.5 million workers from Ukraine may leave Poland' (2019) Gazeta.pl. 14.10.2019 [online]. Available at: http://next.gazeta.pl/ next/7,151003,25307509,w-2020-r-polske-moze-opuscic-nawetpol-miliona-pracownikow.html

41. 'Rules of hiring of doctors from Ukraine will become easier in Poland' (2019) OBOZREVATEL. 24.10.2019 [online]. Available at: https://www.polskieradio.pl/398/7862/Artykul/2390629,yПольщі-спроститься-працевлаштування-лікарів-з-України

42. 'Not only the salary. How Polish employers can keep Ukrainians' (2019) Nasha Polscha. Portal of the association of Ukrainians in Poland. 3.11.2019[online]. Available at: https://nashapolsha.pl/ ne-zarplatoyu-yedynoyu-chym-mozhut-vtrymaty-ukrayintsiv-polski-pratsedavtsi/ 
43. 'Polish language on start'. Learning materials can be downloaded from the website of the Department of foreigners' issues (2019) Me in Poland. 23.10.2019 [online]. Available at: https:// www.yavp.pl/uk/novini/polska-mova-na-start-navchalni-materialymozhna-zavantazhyty-z-saitu-upravlinnia-u-spravakh-inozemtsiv-16680.htm

44. 'Info-line for Ukrainian citizens has created in Poland' (2018) Nasha Polscha. Portal of the association of Ukrainians in Poland. 6.03.2018 [online]. Available at: https://nashapolsha.pl/upolshhi-stvoryly-infoliniyu-dlya-gromadyan-ukrayiny/

45. Murenets, S. (2019)'Wroclaw - the city of opportunities. How migrants from Ukraine are taught to communication, leadership, and success' (2019) Me in Poland. 7.11.2019 [online]. Available at: https://www.yavp.pl/uk/ukrajintsi-v-polshchi/vrotslav-misto-mozhlyvostei-yak-mihrantiv-z-ukrainy-vchat-spilkuvanniu-liderstvu-ta-buty-uspishnymy-16752.html

46. 'Ukrainian earners rooting in Poland more and more' (2019) Nasha Polscha. Portal of the association of Ukrainians in Poland. 19.08.2019 [online]. Available at: https://nashapolsha.pl/ukrayinski-zarobitchany-vse-bilshe-ukorinyuyutsya-v-polshhi/

47. 'Will Ukrainians go from Polish to Germany for work?' Council of Ukraine in Gdansk' comment (2019) Me in Poland. 5.11.2019 [online]. Available at: https://www.yavp.pl/uk/novini/chy-ukraintsipoidut-z-polshchi-na-robotu-do-nimechchyny-komentar-konsulaukrainy-v-hdansku-16746.html

48. Rovenchak, O.A. (2016) 'Socio-cultural characteristics of contemporary Ukrainian migration to Germany' Herald of I.I. Mechnikov ONU. Sociology and political sciences. Vol. 21. No. 1 (24). Pp. 71-90.

49. 'Ukrainian Migration to Poland: A "Local” Mobility? '(2016) Ukrainian Migration to the European Union. Lessons from migration studies / O. Fedyuk, M. Kindler (eds.) ; IMISCOE Research Series. Springer Open, pp. 115-131.
50. Thomas, W., Znaniecki, F. (1920) The Polish Peasant in Europe and America. Core Historical Literature of Agriculture (CHLA). Ithaca, NY: Albert R. Mann Library, Cornell University [online]. Available at: http://chla.library.cornell.edu/c/chla/browse/title/3074959. html

51. Castoriadis, C. (1975) L'Institution imaginaire de la societe. Editions du Seuil.

52. Maffesoli, M. (1996) The Time of the Tribes. The Decline of Individualism in the Mass Society. London : SAGE Publications ; Thousand Oaks, New Delhi.

53. Urry, J. (2000) Sociology beyond Societies. Mobilities for the twenty-first century. London and New York : Routledge.

54. Brzozowska, A., Grzymała-Kazłowska, A. (2017) 'From Drifting to Anchoring Capturing the Experience of Ukrainian Migrants in Poland'. Central and Eastern European Migration Review. Vol. 6. No. 2, pp. 103-122

55. Shestakovskyi, O. (2014) Current tendencies of Ukrainian transnational labor migration as social mobility. Social mobility processes in contemporary Ukrainian society. O. Balakirieva (ed.). Kyiv : Institute of economics and prognosis. Pp. 171-202.

56. Rovenchak, O., Khymovych, O. (2018) 'Identity of potential migrant and migrational identity: formation and respective practices'. Sociology: theory, methods, marketing. №2, pp. 97-116.

57. Musiyezdov, O. (2016) Urban identity in (Post)modern Ukrainian city (case of Kharkiv and Lviv). Sociology: theory, methods, marketing. №3, pp. 94-110.

58. 'The Naked City' - Speaker: Professor Sharon Zukin (2011) Youtube. London School of Economics and Political Science (LSE). 5.05.2011 [online]. Available at: https://www.youtube.com/ watch?v=0J6aymGN2Vo 